\title{
HUBUNGAN KARAKTERISTIK RESPONDEN DENGAN KUALITAS HIDUP PENDERITA KATARAK
}

\section{THE CORRELATION BETWEEN CHARACTERISTICS OF RESPONDENTS WITH THE QUALITY OF LIFE PATIENTS WITH CATARCT}

\author{
Nur Fadhilah ${ }^{1}$, Nur Nasry Noor ${ }^{2}$ Stang $^{3}$, Andi Hardianti ${ }^{1}$ \\ ${ }^{1}$ Fakultas Kesehatan Masyarakat, Universitas Hasanuddin \\ ${ }^{2}$ Departemen Epidemiologi, Fakultas Kesehatan Masyarakat, Universitas Hasanuddin \\ ${ }^{3}$ Departemen Biostatistik, Fakultas Kesehatan Masyarakat, Universitas Hasanuddin \\ Alamat Koresponden: Fakultas Kesehatan Masyarakat Universitas Hasanuddin Makassar, \\ 90245, nurfadhilahkasim@gmail.com
}

\begin{abstract}
Abstrak
Katarak adalah proses degeneratif berupa kekeruhan di lensa bola mata sehingga menyebabkan menurunnya kemampuan penglihatan sampai kebutaan. Katarak merupakan penyebab kebutaan terbanyak di seluruh dunia. Penelitian ini bertujuan mengetahui faktor-faktor yang berhubungan dengan kualitas hidup penderita katarak. Penelitian ini adalah penelitian kuantitatif dengan metode cross sectional yang dilakukan di Balai Kesehatan Mata Masyarakat Makassar. Populasi dalam penelitian ini adalah penderita katarak yang telah menjalani operasi sebanyak 698. Penarikan sampel dilakukan secara consecutive sampling sehingga diperoleh jumlah sampe sebanyak 250 responden. Data dianalisis menggunakan uji chi square dan regresi logistik. Hasil penelitian menunjukkan sebagian besar responden memiliki kualitas hidup baik (70.4\%). Faktor yang berhubungan dengan kualitas hidup penderita katarak adalah jenis kelamin $(\mathrm{p}=0.047)$, pendidikan $(\mathrm{p}=0.000)$, pekerjaan $(\mathrm{p}=0.000)$. Hasil analisis regresi logistik menunjukkan bahwa umur merupakan faktor yang yang paling berhubungan dengan kualitas hidup penderita katarak (OR=5984; CI 95\% 3.018-11.865).
\end{abstract}

Kata Kunci: Kualitas Hidup, Katarak, Balai Kesehatan Mata Masyarakat Makassar

\begin{abstract}
Cataract is a degenerative process of turbidity in the lens of the eyeball causing decreased vision ability until blindness. Cataract is the leading cause of blindness worldwide. This study aims to determine the factors associate with the quality of life of patients with cataracts. This research is a quantitative research with cross sectional method which is done at Eye Health Community Center Makassar. The population in this study were 698 cataract patients who had undergone surgery. Samples were taken by consecutive sampling with number of sample of 250 respondents. Data were analyzed using chi square test and logistic regression. The results showed most respondents have good quality of life $(70.4 \%)$. Factors related to the quality of life of cataract patients were gender ( $p$ value $=0.047)$, education $(p=0.000)$, employment $(p=0.000)$. The result of logistic regression analysis showed that education was the factor most correlated factor with quality of life for cataract patients $(O R=5.984 ; 95 \%$ CI 3.01811.865).
\end{abstract}

Keywords: Quality of Life, Cataract, Eye Health Center Community Makassar 


\section{PENDAHULUAN}

Katarak adalah proses degeneratif berupa kekeruhan di lensa bola mata sehingga menyebabkan menurunnya kemampuan penglihatan sampai kebutaan. Kekeruhan ini disebabkan oleh terjadinya reaksi biokimia yang menyebabkan koagulasi protein lensa. Katarak bisa terjadi secara kongenital (katarak sejak lahir), namum pada umumnya katarak terjadi karena proses degenerasi yang berhubungan dengan penuaan atau bisa juga karena trauma dan induksi dari obat-obatan (steroid, klorpromazin, alupurinol, amiodaron). Komplikasi dari kondisi sistemik seperti diabetes mellitus atau penyakit mata seperti glaukoma dengan uveitis juga dapat mempercepat terjadinya proses katarak (Kemenkes RI, 2016a, Kemenkes RI, 2016b).

Sekitar 253 juta orang hidup dengan gangguan penglihatan di seluruh dunia, di mana 36 juta orang mengalami kebutaan. Sebesar $80 \%$ gangguan penglihatan termasuk kebutaan dapat dihindari. Secara global penyebab utama gangguan penglihatan adalah kelainan refraksi (43\%), katarak (33\%). Penyebab lainnya adalah glaukoma (2\%), degenerasi makular terkait usia (Agerelated Macular Degeneration - AMD), retinopati diabetik, trakoma dan ulkus kornea sekitar $1 \%$ dan sebesar $18 \%$ tidak dapat ditentukan. Sedangkan penyebab kebutaan terbanyak adalah katarak yaitu sebesar $51 \%$ (WHO, 2012, WHO, 2017).

Prevalensi kebutaan yang diakibatkan oleh katarak tetap tinggi meskipun jumlahnya menurun di beberapa wilayah di seluruh dunia. Prevalensi kebutaan pada orang dewasa yang berusia lebih dari 50 tahun paling tinggi di Sub-Sahara Afrika bagian barat sebesar $6,0 \%$. Penurunan terbesar kebutaan yang diakibatkan oleh katarak pada orang dewasa yang berusia $\geq 50$ tahun sejak tahun 1990-2010 berada di wilayah Asia Timur, Amerika Latin dan Eropa Barat. Hasil studi juga menunjukkan bahwa angka kejadian katarak lebih tinggi pada perempuan dibandingkan laki-laki (Lee and Afshari, 2017).

Angka kebutaan di Indonesia menempati urutan ketiga di dunia. Bahkan kebutaan di Indonesia merupakan yang terburuk di Asia dan ASEAN. Hingga saat ini sekitar 3,1 juta (15\%) penduduk Indonesia mengalami kebutaan. Angka tersebut lebih tinggi dibandingkan negara-negara miskin seperti Bangladeh (1,0\%), India (0,7\%), dan Thailand (0,3\%) (WHO, 2012).

Hasil Riset Kesehatan Dasar tahun 2013 menunjukkan bahwa prevalensi kebutaan di Indonesia pada penduduk usia $\geq 6$ tahun mengalami penurunan jika 
dibandingkan pada tahun 2007 yaitu dari 0,9\% pada tahun 2007 menjadi 0,4\% pada tahun 2013. Katarak merupakan penyebab utama kebutaan di Indonesia. Prevalensi katarak secara nasional sebesar 1,8\%. Prevalensi katarak tertinggi di Sulawesi Utara $(3,7 \%)$ diikuti oleh Jambi $(2,8 \%)$ dan Bali $(2,7 \%)$. Prevalensi katarak terendah ditemukan di DKI Jakarta sebesar 0,9\% dan $1,1 \%$ di Sulawesi Barat (Balitbangkes Kemenkes RI, 2013).

Sebagian besar penduduk dengan katarak di Indonesia belum menjalani operasi katarak. Tiga alasan utama penderita katarak belum menjalani operasi adalah karena ketidaktahuan (51,6\%), ketidakmampuan $(11,6 \%)$, dan ketidakberanian $(8,1 \%)$ (Balitbangkes Kemenkes RI, 2013).

Balai Kesehatan Mata Masyarakat Makassar merupakan salah satu tempat rujukan untuk penyakit mata di wilayah timur Indonesia. Penelitian ini bertujuan untuk menganalisis hubungan karakteristik responden dengan kualitas hidup penderita katarak di Balai Kesehatan Mata Masyarakat Makassar.

\section{BAHAN DAN METODE}

\section{Lokasi dan Rancangan Penelitian}

Peneltian ini dilaksanakan di Balai Kesehatan Mata Masyarakat Makassar. Jenis penelitian yang digunakan adalah studi observasional analitik dengan melakukan pendekatan cross sectional study.

\section{Populasi dan Sampel}

Populasi pada penelitian ini adalah semua penderita katarak yang telah menjalani operasi katarak pada Januari tahun 2018 di Balai Kesehatan Mata Masyarakat Kota Makassar sebanyak 698 orang. Sampel pada penelitian ini yakni penderita katarak yang telah menjalani operasi katarak di Balai Kesehatan Mata Masyarakat Makassar yaitu sebanyak 250 responden yang dipilih dengan menggunakan teknik consecutive sampling. Sampel penelitian responden yang bersedia menjadi responden selama penelitian berlangsung dengan menandatangani informed consent yang telah dikeluarkan oleh Komite Etik Fakultas Kesehatan Masyarakat Universitas Hasanuddin. Responden terdaftar sebagai penderita katarak pada buku register/rekam medik Balai Kesehatan Mata Masyarakat Makassar dan memiliki catatan medis yang lengkap dan memenuhi kriteria variabel yang diteliti.

\section{Metode Pengumpulan Data}

Pengumpulan data primer diperoleh dengan cara melakukan wawancara langsung ke responden dengan berpedoman pada kuesioner yang telah tersedia yang memuat pertanyaan untuk menggali informasi mengenai variabel umur, jenis kelamin, 
Fadhilah, 2019

pendidikan, lama sakit, riwayat penyakit.

Kuesioner terkait kualitas hidup menggunakan National Eye Institute Visual Function Questionnaire 25 (NEI-VFQ25). Pengumpula data sekunder menggunakan data rekam medis yang diambil dari Balai Kesehatan Mata Masyarakat Makassar.

\section{Analisis Data}

Analisis data dilakukan menggunakan Statistical Package for Social Science (SPSS) versi 21. Uji chi-square digunakan untuk menguji hubungan antara variabel independen dan dependen dengan dengan signifikansi statistik diterima pada tingkat kepercayaan 95\%. Analisis regresi logistik dilakukan untuk mengidentifikasi faktor yang terkait dengan kualitas hidup dengan menyesuaikan kovariat. Analisis variabel dengan $p$-value $<$ 0,25 dimasukkan dalam analisis model regresi logistik dengan menggunakan metode Backward Stepwise (LR) untuk mengidentifikasi faktor yang paling berhubungan dengan kualitas hidup penderita katarak.

\section{HASIL}

Persentase kualitas hidup penderita katarak di Balai Kesehatan Mata Masyarakat Makassar lebih banyak yang memiliki kulitas hidup baik yaitu sebesar $70.4 \%$. Responden dengan kualitas hidup buruk yaitu sebesar $29.6 \%$ (Tabel 1).

Hasil analisis bivariat menunjukkan bahwa jenis kelamin laki-laki yang menderita katarak dengan kualitas hidup yang baik yaitu $77.1 \%$ sedangkan jenis kelamin perempuan yang memiliki kualitas hidup baik sebesar 65.5\%. Distribusi responden dengan kualitas hidup baik yang paling tinggi pada responden dengan kategori pendidikan tinggi sebesar $86.9 \%$. Sedangkan distribusi responden dengan kualitas hidup buruk paling tinggi pada responden dengan kategori pendidikan rendah sebesar $49.6 \%$. Berdasarkan status pekerjaan responden, sebagian besar responden memiliki kualitas hidup baik yaitu yang memiliki pekerjaan sebesar $79.6 \%$ dan yang memiliki kualitas hidup buruk paling tinggi pada responden yang tidak memiliki pekerjaan sebesar $40.7 \%$. Variabel jenis kelamin $(p=0.047)$, pendidikan $(p=0.000)$ dan status pekerjaan $(p=0.000)$ berhubungan secara signifikan dengan kualitas hidup penderita katarak di Balai Kesehatan Mata Masyarakat Makassar (Tabel 2).

Tabel 3 menunjukkan hasil analisis regresi logistik dimana pendidikan merupakan variabel yang paling berhubungan dengan kualitas hidup penderita katarak di Balai Kesehatan Mata Masyarakat Makassar sebesar 5.984 kali (CI 95\% : 3.018-11.865). 
Tabel 1. Kualitas Hidup Penderita Katarak di Balai Kesehatan Mata Masyarakat Makassar Tahun 2018

\begin{tabular}{lccc}
\hline Kualitas Hidup & $\begin{array}{c}\text { Frekuensi } \\
(\mathbf{n = 2 5 0 )}\end{array}$ & \% \\
\hline Baik & 176 & 70.4 \\
Buruk & 74 & 29.6 \\
\hline
\end{tabular}

Sumber: Data Primer 2018

Tabel 2. Hubungan Karakteristik Responden dengan Kualitas Hidup Penderita Katarak di Balai Kesehatan Mata Masyarakat Makassar Tahun 2018

\begin{tabular}{|c|c|c|c|c|c|c|c|}
\hline \multirow{3}{*}{ Karakteristik } & \multicolumn{4}{|c|}{ Kualitas Hidup $(n=250)$} & \multirow{2}{*}{\multicolumn{2}{|c|}{ Total }} & \multirow{3}{*}{$p$ value } \\
\hline & \multicolumn{2}{|c|}{ Buruk } & \multicolumn{2}{|c|}{ Baik } & & & \\
\hline & $\mathbf{n}$ & $\%$ & $\mathbf{n}$ & $\%$ & $\mathbf{n}$ & $\%$ & \\
\hline \multicolumn{8}{|l|}{ Jenis Kelamin } \\
\hline Laki-laki & 24 & 22.9 & 81 & 77.1 & 105 & 100 & \multirow{3}{*}{0.047} \\
\hline Perempuan & 50 & 34.5 & 95 & 65.5 & 145 & 100 & \\
\hline Jumlah & 74 & 29.6 & 176 & 70.4 & 250 & 100 & \\
\hline \multicolumn{8}{|l|}{ Pendidikan } \\
\hline Rendah & 56 & 49.6 & 57 & 50.4 & 113 & 100 & \multirow{3}{*}{0.000} \\
\hline Tinggi & 18 & 13.1 & 119 & 86.9 & 137 & 100 & \\
\hline Jumlah & 74 & 29.6 & 176 & 70.4 & 250 & 100 & \\
\hline \multicolumn{8}{|l|}{ Status Pekerjaan } \\
\hline Tidak bekerja & 46 & 40.7 & 67 & 59.3 & 113 & 100 & \multirow{3}{*}{0.000} \\
\hline Bekerja & 28 & 20.4 & 109 & 79.6 & 137 & 100 & \\
\hline Jumlah & 74 & 29.6 & 176 & 70.4 & 250 & 100 & \\
\hline
\end{tabular}

Sumber: Data Primer 2018

Tabel 3. Analisis Regresi Logistik Berganda Hubungan Karakteristik Responden dengan Kualitas Hidup Penderita Katarak di Balai Kesehatan Mata Masyarakat Makassar Tahun 2018

\begin{tabular}{|c|c|c|c|c|c|c|}
\hline \multirow{2}{*}{$\begin{array}{c}\text { Variabel } \\
\text { Penelitian }\end{array}$} & \multirow{2}{*}{ B } & \multirow{2}{*}{ Wald } & \multirow{2}{*}{ Sig. } & \multirow{2}{*}{$\operatorname{Exp}(B)$} & \multicolumn{2}{|c|}{ CI $95 \%$} \\
\hline & & & & & $\mathbf{L L}$ & $\mathbf{U L}$ \\
\hline Jenis Kelamin & -0.286 & 0.656 & 0.418 & 0.751 & 0.376 & 1.500 \\
\hline Pekerjaan & 0.093 & 0.062 & 0.803 & 1.098 & 0.528 & 2.283 \\
\hline Pendidikan & 1.789 & 26.248 & $0.000 *$ & 5.984 & 3.018 & 11.865 \\
\hline Constant & -1.780 & 28.136 & 0.000 & 0.169 & & \\
\hline
\end{tabular}

\section{PEMBAHASAN}

Hasil penelitian ini menunjukkan bahwa karakterik respoden yaitu jenis kelamin, pendidikan dan pekerjaan secara signifikan memiliki hubungan dengan 
kualitas hidup penderita katarak di Balai Kesehatan Mata Masyarakat Makassar.

Jenis kelamin menjadi salah satu faktor yang berhubungan dengan kualitas hidup penderita katarak. Nejad et al. (2016) bahwa ada hubungan antara jenis kelamin dengan kualitas hidup penderita gangguan penglihatan. Kualitas hidup secara signifikan lebih rendah pada perempuan dibandingkan pada laki-laki. Hal tersebut terkait dengan faktor budaya yang dapat berkontribusi terhadap kualitas hidup rendah pada wanita. Fardna (2018) menyatakan bahwa kualitas hidup dilihat dari domain psikologis dan kepuasan terhadap status kesehatan saat ini lebih buruk pada wanita sedangkan berdasarkan domain sosial lebih buruk pada pria.

Penelitian oleh Ahmad et al. (2016) menyatakan bahwa ada hubungan antara jenis kelamin dengan kualitas hidup. Kesehatan mental pada perempuan lebih rendah daripada laki-laki. Perempuan berisiko mengalami depresi lebih besar daripada lakilaki. Perbedaan yang terjadi dapat terjadi dikarenakan coping strategies laki-laki dan perempuan yang berbeda. Pria cenderung berfokus pada masalah yang terjadi sedangkan wanita lebih fokus pada emosi saat menghadapi masalah sehingga wanita lebih cenderung mempunyai emosi negatif yang dalam jangka waktu lama dapat menyebabkan stress dan menurunnya kualitas hidup. Secara biologis, perempuan lebih berpeluang mengalami stres karena adanya dysregualted pitutary-hipotalamus-adrenal axis (HPA) untuk merespon stres lebih baik laki-laki. Namun berbeda dengan penelitian Campos et al. (2014) yang menyatakan bahwa bahwa wanita dengan kesehatan fisik dan psikososial yang baik cenderung memiliki kualitas hidup yang lebih baik.

Ada hubungan yang signifikan antara pendidikan dengan kualitas hidup penderita katarak di Balai Kesehatan Mata Masyarakat Makassar. Penderita katarak dengan kualitas hidup baik lebih banyak pada responden dengan kategori pendidikan tinggi. Temuan ini sejalan dengan penelitian Onakoya et al. (2012) mengemukakan bahwa semakin tinggi pendidikan maka akan semakin baik kualitas hidupnya. Semakin tinggi pendidikan, maka seseorang memiliki pemahaman yang baik mengenai penyakit yang dideritanya. 
Penelitian oleh Abrori (2017) menyatakan bahwa tingkat pendidikan adalah salah satu faktor yang dapat mempengaruhi kualitas hidup. Kualitas hidup akan meningkat seiring tingkat pendidikan individu. Seseorang yang mempunyai pendidikan lebih tinggi mempunyai kemampuan belajar lebih cepat dan pada umumnya memiliki basis pengetahuan yang lebih luas yang dapat membantu memperkuat informasi baru. Sharma et al. (2014) menjelaskan bahwa pengetahuan merupakan domain untuk membentuk tindakan. Penderita berpendidikan tinggi memiliki pengetahuan lebih luas sehingga dapat mengontrol diri dalam mengatasi masalah yang dihadapi. Tingkat pendidikan juga memengaruhi matangnya perubahan diri seseorang untuk menerima pengaruh luar yang positif terkait dengan informasi kesehatan sehingga dengan mudahnya penerimaan informasi tersebut, akan memudahkan penderita melakukan manajemen perawatan (Meidikayanti and Wahyuni, 2017).

Ada hubungan antara status pekerjaan dengan kualitas hidup penderita katarak. Sebagian besar responden memiliki kualitas hidup baik yaitu yang memiliki pekerjaan. Penderita dengan umur produktif yang memiliki pekerjaan merasa termotivasi untuk sembuh, mempunyai harapan hidup yang tinggi, dan menjadi tulang punggung keluarga. (Abrori and Ahmad, 2017).

Hasil penelitian oleh Juanita and Safitri (2016) menunjukkan bahwa pasien yang bekerja memiliki kualitas hidup yang lebih tinggi dibandingkan pasien yang tidak bekerja. Hal ini dikarenakan pada pasien yang bekerja aktifitas yang dilakukan lebih banyak dan mempunyai kesempatan lebih besar untuk bersosialisasi dengan orang lain, sehingga tidak terlalu memikirkan penyakit yang diderita. Namun berbeda dengan penelitian Rochmayanti (2011) yang menyatakan bahwa tidak ada hubungan antara pekerjaan dengan kualitas hidup. Tidak adanya hubungan kualitas hidup antara pasien yang bekerja dengan yang tidak bekerja disebabkan oleh dampak dari penyakit yang ditimbulkan dalam mempengaruhi aktivitas.

\section{KESIMPULAN DAN SARAN}

Pendidikan merupakan variabel yang paling berhubungan dengan kualitas hidup penderita katarak di Balai Kesehatan Mata Masyarakat Makassar. Untuk mempertahankan kualitas hidup penderita katarak, perlu dideteksi sedini mungkin faktor-faktor yang mempengaruhi kualitas hidup penderita. Perlunya sosiaisasi 
pentingnya pemeriksaan mata bagi kelompok

berisiko tinggi yaitu orang tua agar tidak berakhir dengan kebutaan. Sosialisasi tidak hanya pada kelompok yang berisiko tinggi juga pada keluarga agar mengetahui gejala awal dari katarak.

\section{DAFTAR PUSTAKA}

Abrori, I. \& Ahmad, R. A. (2017). Kualitas Hidup Penderita Tuberkulosis Resisten Obat di Kabupaten Banyumas. BKM Journal of Community Medicine and Public Health, 34: 56-61.

Ahmad, N., Javaid, A., Sulaiman, S. A. S., Basit, A., Afridi, A. K., Jaber, A. A. S. \& Khan, A. H. (2016). Effects of Multidrug Resistant Tuberculosis Treatment on Patients' Health Related Quality of Life: Results from a Follow Up Study. Plos One, 1-16.

Balitbangkes Kemenkes RI. (2013). Riset Kesehatan Dasar 2013. Jakarta: Badan Penelitian dan Pengembangan Kesehatan Kementerian Kesehatan Republik Indonesia.

Campos, A. C. V., Ferreira, E., Vargas, A. M. D. \& Albala, C. (2014). Aging, Gender and Quality of Life (AGEQOL) Study: Factors Associated With Good Quality of Life in Older Brazilian CommunityDewlling Adults. Biomed Central, 12:1-11.

Juanita \& Safitri, C. P. (2016). Hubungan Basic Conditioning Factors dengan Kualitas Hidup Lanjut Usia dengan Diabetes Melitus di RSUD Dr. Zainoel Abidin Banda Aceh. Idea Nursing Journal, 7:48-60.

Kemenkes RI. (2016a). Katarak, Kenali Gejala Dininya. Direktorat Pencegahan dan Pengendalian
Penyakit Tidak Menular Kementerian Kesehatan Republik Indonesia. [cited 2018 Jan 15].

Kemenkes RI (2016b). Profil Penyakit Tidak Menular 2016. Jakarta: Kementerian Kesehatan Republik Indonesia.

Lee, C. M. \& Afshari, N. A. (2017). The Global State of Cataract Blindness. National Center for Biotechnology Information - Pubmed, 28:98-103.

Meidikayanti, W. \& Wahyuni, C. U. (2017). Hubungan Dukungan Keluarga dengan Kualitas Hidup Diabetes Melitus Tipe 2 di Puskesmas Pademawu (Tesis). Surabaya: Universitas Airlangga.

Nejad, M. K., Sarabandi, A., Akbari, M.-R. \& Askarizadeh, F. (2016). The Impact of Visual Impairment on Quality of Life. Medical Hypothesis, Discovery \& Innovation Opthalmology Journal, 5:96-103.

Onakoya, A. O., Mbadugha, C. A., Aribaba, O. T. \& Ibidapo, O. O. (2012). Quality of life of primary open angle glaucoma patients in Lagos, Nigeria: clinical and sociodemographic correlates. Journal of glaucoma, 21:287-295.

Rochmayanti. (2011). Analisis Faktor-Faktor yang Memperngaruhi Kualitas Hidup Pasien Penyakit Jantung Koroner di Rumah Sakit Pelni (Tesis). Jakarta: Universitas Indonesia.

Sharma, R., Yadav, R., Sharma3, M., Saini, V. \& Koushal, V. (2014). Quality of Life of Multi Drug Resistant Tuberculosis Patients: A Study of North India. Acta Medica Irananica, 52:448-453.

WHO. (2012). Global Data On Visual Impairments 2010. Geneva: World Health Organization .

WHO. (2017). Vision Impairment and Blindness. Geneva: World Health Organization. [cited 2018 Jan 15]. 